\title{
MALDI-TOF MASS SPECTROMETRY IDENTIFICATION OF YEAST-FORM FUNGI: A COMPARISON BETWEEN METHODS
}

\author{
Max Roberto Batista Araújo1, Luisa Ferreira Seabra1, \\ Mireille Ângela Bernardes Sousa ${ }^{1}$
}

Clin Biomed Res. 2019;39(2):128-135

1 Núcleo Técnico Operacional, Setor de Microbiologia, Instituto Hermes Pardini. Vespasiano, MG, Brasil.

Corresponding author: Max Roberto Batista Araújo max_barau@hotmail.com Instituto Hermes Pardini Av. das Nações, 2448 33200-000, Vespasiano, MG, Brasil.

\begin{abstract}
Introduction: Identification of yeast species has clinical and epidemiological value. Different methods can be used, such as chromogenic media, microculture on corn meal agar with Tween 80, as well as conventional biochemical and automated methods. Recently, proteomic studies employing matrix-assisted laser desorption ionization-time of flight (MALDI-TOF) mass spectrometry have been a major advance in diagnosis due to speed of execution and accuracy of results.
\end{abstract}

Methods: For this study, 79 yeast samples were submitted to identification using chromogenic medium, microculture on corn meal-Tween 80 agar, VITEK ${ }^{\circledR} 2$ Compact identification, and MALDI-TOF mass spectrometry.

Results: Most of the 79 samples were identified, with differences in the performance of the methods used. Colonial morphology and microscopy were compatible with the genus Candida. MALDI-TOF mass spectrometry had the best performance, with 78 strains identified $(98.7 \%)$, compared to VITEK ${ }^{\circledR} 2$ Compact $(92.4 \%)$ and microculture on corn meal agar $(70.9 \%)$.

Conclusions: MALDI-TOF mass spectrometry using the VITEK ${ }^{\circledR}$ MS instrument performed best and has proven to be a revolutionary method in clinical microbiology laboratories. Regarding the identification of $C$. albicans and $C$. tropicalis, the chromogenic medium had excellent performance, thus being a good option to optimize the process.

Keywords: Mass spectrometry; matrix-assisted laser desorption-ionization; candidiasis; Candida; yeasts

There is a constant search for better diagnostic and therapeutic approaches in order to prolong life. The use of antimicrobials, immunosuppressive drugs, and invasive procedures are some examples of methods used for this purpose. However, such aggressive strategies of surgical and clinical care favor an increase in the incidence of yeast infections, as opposed to the initially sought goal ${ }^{1-5}$.

Candida albicans is the most common pathogen in cutaneous and oropharynx candidiasis, but other species have increased in number and importance in other types of candidiasis, mainly vaginal and systemic ${ }^{6}$. Thus, although $C$. albicans is most common in clinical samples, other species have been reported as important opportunistic pathogens ${ }^{7,8}$.

In this context, several Candida species have been described, but not all of them correlate with infections in humans. Only $10 \%$ of these species have clinical relevance, being C. albicans, C. parapsilosis, C. tropicalis, C. glabrata, and C. krusei the most incidental, accounting for $90 \%$ of cases of invasive candidiasis ${ }^{9}$.

In a laboratory environment, there are different ways that allow the identification of the various Candida spp. from clinical samples ${ }^{10}$. One of them is the use of identification procedures based on biochemical tests and morphological studies, but these may not be practical and fast enough, in addition to requiring a broader level of knowledge ${ }^{11}$. Packaged kit systems 
and automated systems are another option, but they are expensive and limited by the size of their databases $^{12}$. Thus, because of a need for rapid pathogen identification, differential media were developed, allowing the isolation and identification of the Candida spp $^{13}$. based on the formation of colonies with different morphologies and colors ${ }^{14}$.

Regardless of, there is variability in pathogenicity and sensitivity to available antifungal agents according to the species involved. In addition, the incidence of infections caused by non-albicans Candida spp. is increasing, often involving high mortality rates ${ }^{15-17}$. Therefore, a precise identification of the species involved in infectious processes is necessary.

As there are several clinical manifestations and species involved in Candida spp. infections, using different diagnostic methods has become fundamental. Among the instruments used for this purpose are chromogenic media, microculture on corn meal agar, and conventional biochemical (Zymogram and Auxonogram) and automated methods (commercially available panels or cards). More recently, proteomic studies using matrix-assisted laser desorption ionization-time of flight (MALDI-TOF) mass spectrometry have represented a major advance in diagnosis due to speed of execution and accuracy of results ${ }^{18}$.

Thus, based on the clinical, epidemiological and laboratory importance of the infections caused by different Candida spp., this study compared the performance of different methods and proposes a standardization to optimize the routine identification of yeasts isolated from clinical samples.

\section{METHODS}

For this study, 75 clinical yeast isolates from different biological materials and four standard strains (C. parapsilosis ATCC 22019, C. albicans ATCC 10231, C. krusei ATCC 6258 and C. krusei ATCC 14243) were analyzed. In order to perform a rapid and accurate identification of the species, all samples were submitted to four different methods with subsequent analysis to ascertain the best performance.

\section{Identification of Strains by CHROMagar ${ }^{\circledR}$ Candida (CHROMagar ${ }^{\circledR}$, Plast Labor, Brazil)}

There are many options for chromogenic culture media capable of differentiating $C$. albicans and other yeast species. They are based on the alteration of the color acquired by the colonies through $\mathrm{pH}$ and fermentation indicators of specific compounds or chromogenic substrates ${ }^{19-22}$.
The samples were seeded in CHROMagar ${ }^{\circledR}$ Candida medium (CHROMagar ${ }^{\circledR}$, Plast Labor, Brazil), which is selective for the isolation and presumptive identification of yeast fungi, allowing the differentiation of $C$. albicans (green colony), C. tropicalis (metallic blue colony) and C. krusei (pink colony). Incubation was performed aerobically at $35^{\circ} \mathrm{C} \pm 2{ }^{\circ} \mathrm{C}$ for 36-48 hours, and quality control was performed with ATCC 10231 (C. albicans), ATCC 6258 (C. krusei) and ATCC 1369 (C. tropicalis).

\section{Identification of Strains by Microculture on Corn Meal-Tween 80 Agar}

This culture is used to analyze micromorphology. The characteristics of pseudomycelium, pseudohyphae, true hyphae and blastoconidia form and disposition, with presence or not of chlamydoconidia, allow the differentiation of species when associated with physiological behavior ${ }^{23}$.

Corn meal-Tween 80 agar medium was prepared according to specifications ${ }^{24}$. A small block of approximately $4 \mathrm{~mm}$ thickness was placed on a slide and then into a sterile Petri dish lined with filter paper soaked in liquid glycerin and water. Yeasts were applied to the surface of the block and covered by a coverslip. After incubation at $28^{\circ} \mathrm{C}$ for $48-72$ hours, readings were made using an optical microscope at magnifications of 100 to 400 times. More than $90 \%$ of $C$. albicans isolates produced chlamydoconidia ${ }^{25}$.

\section{Identification of Strains by Biochemical Tests in VITEK ${ }^{\circledR}$ Compact (bioMérieux, Brazil)}

The strains were submitted to automated identification by inoculation on the VITEK ${ }^{\circledR} 2$ Compact System (bioMérieux) in the YEAST-ID (VITEK ${ }^{\circledR} 2$-YST) card following the technique recommended by the manufacturer. This yeast identification card is based on established biochemical methods and on developed substrates. There are 46 biochemical tests that measure the use of the carbon source, the use of nitrogen source and enzymatic activity. The results are available in approximately 18 hours $^{26}$. The list of test substrates is shown in Table 1.

The inoculum for identification was prepared using colonies isolated from yeasts in physiological solution. The turbidity was measured by the instrument DensiCheck ${ }^{\circledR}$ (bioMérieux, Brazil) and equivalent to 1.8-2.2 of the McFarland scale. Through a polystyrene tube, samples were dispensed on the YST cards that were placed in the apparatus, through incubation and reading of the samples. The data obtained were interpreted by the database of the instrument, providing the final identification of the strains. 
Table 1: Test substrates on VITEK ${ }^{\circledR}$ 2-YST card.

\begin{tabular}{|c|c|c|c|}
\hline Test & Mnemonic & Test & Mnemonic \\
\hline L-Lysine-Arylamidase & LysA & L-Sorbose assimilation & ISBEa \\
\hline L-Malate assimilation & IMLTa & L-Rhamnose assimilation & IRHAa \\
\hline Leucine-Arylamidase & LeuA & Xylitol assimilation & XLTa \\
\hline Arginine GP & ARG & D-Sorbitol assimilation & dSORa \\
\hline Erythritol assimilation & ERYa & Saccharose assimilation & SACa \\
\hline Glycerol assimiliation & GLYLa & Urease & URE \\
\hline Tyrosine-Arylamidase & TyrA & Alpha-Glucosidase & AGLU \\
\hline D-Gluconate assimilation & dGNTa & D-Turanose assimilation & dTURa \\
\hline Arbutin assimilation & $\mathrm{ARBa}$ & D-Trehalose assimilation & dTREa \\
\hline Amygdalin assimilation & AMYa & Nitrate assimilation & NO3a \\
\hline D-Galactose assimilation & dGALa & L-Arabinose assimilation & IARAa \\
\hline Gentobiose assimilation & GENa & D-Galacturonate assimilation & dGATa \\
\hline D-Glucose assimilation & dGLUa & Esculin hydrolysis & ESC \\
\hline Lactose assimilation & $\mathrm{LACa}$ & L-Glutamate assimilation & IGLTa \\
\hline Glucuronate assimilation & GRTas & D-Xylose assimilation & dXYLa \\
\hline D-Cellobiose assimilation & dCELa & Acetate assimilation & ACEa \\
\hline DL-Lactate assimilation & LATa & Citrate assimilation & $\mathrm{CITa}$ \\
\hline D-Maltose assimilation & dMALa & D-Melezitose assimilation & $\mathrm{dMLZa}$ \\
\hline D-Raffinose assimilation & dRAFa & D-Melibiose assimilation & dMELa \\
\hline L-Proline assimilation & IPROa & D-Mannose assimilation & dMNEa \\
\hline 2-Keto-D-Gluconate assimilation & $2 \mathrm{KGa}$ & $\mathrm{N}$-acetyl-Glucosamine assimilation & NAGa \\
\hline Beta-N-Acetil-Glucosaminidase & BNAG & Gamma-Glutamyl Transferase & GGT \\
\hline Methyl-A-D-Glucopyranoside assimilation & MAdGa & PNP-N-acetyl-BD galactosaminidase 1 & NAGA 1 \\
\hline
\end{tabular}

\section{Identification of Strains by MALDI-TOF Mass Spectrometry (VITEK ${ }^{\circledR}$ MS, bioMérieux, France)}

The technology is based on the fact that different mass and charge ions, when subjected to an electric field, move and the distance traveled in a given time is a function of the mass/charge ratio. The first step is to mix the sample with the matrix, and then evaporate the solvents and crystallize the mixture. The deposit formed by the sample and the matrix is carried out on a metal plate. The plate is introduced into the apparatus and specific UV laser beams are emitted on each reservoir. The matrix absorbs the energy of the laser and evaporation of the sample occurs with the formation of ions with different masses. The ions move under the influence of the electric field and the smaller ones arrive more quickly to the detector located at one end of the flight tube. The flight time of each particle to the detector is used to calculate its mass. The sum of ions analyzed forms the mass spectrum of the sample; one axis corresponds to the mass/charge ratio and the other one corresponds to the signal intensity that is related to the number of ions of the same mass/charge ratio ${ }^{27}$.

Thus, the obtained mass spectra are processed by a specific software, namely MYLA ${ }^{\circledR}$ (bioMérieux, France), and compared to the database containing the reference spectra or "super spectra". The VITEK ${ }^{\circledR}$ MS (bioMérieux) instrument compares these spectra with the Spectral Archive and Microbial Identification System (SARAMIS, bioMérieux, France) database, which in turn uses common peaks of strains of the same species (between 15-20) to build a "super spectrum". Finally, agreement values above $60 \%$ mean the species was identified.

For yeast samples, preparations were lysed with $0.5 \mu \mathrm{L} 25 \%$ formic acid. After drying completely at room temperature (1 to $2 \mathrm{~min}$ ), $1 \mu \mathrm{L}$ of a-cyano-4hydroxycinnamic acid (CHCA) matrix (bioMérieux) was applied to the spot, which was also allowed to dry completely (1 $\mathrm{min})$. As recommended by the manufacturer's instructions, the Escherichia coli ATCC 8739 strain, used as a calibrator and internal ID control, was inoculated on the calibration spots of each acquisition group (small spot in the middle of each acquisition group). Each yeast isolate had been tested with a unique deposit.

In addition, strains ATCC 19433 (Enterococcus faecalis) and ATCC MYA-2950 (C. glabrata) were used as internal control. A negative control performed only with the matrix, without adding the sample, was also applied.

\section{RESULTS AND DISCUSSION}

Invasive fungal infections are relevant in clinical practice, as they can be serious and represent important causes of morbidity and mortality worldwide ${ }^{28,29}$. Thus, 
improvement of patients' conditions and even their survival depends on a rapid and accurate identification of the pathogen, allowing a timely introduction of antifungal therapy.

In the present study, different yeast samples were submitted to different methods, which provided an evaluation of their performance in the laboratory routine. The results of the identification techniques are presented in Table 2 and will be discussed in comparison with the results obtained by MALDI-TOF mass spectrometry (VITEK $\left.{ }^{\circledR} \mathrm{MS}\right)$.
One of the alternatives for distinguishing between Candida spp. is commercially available chromogenic media. Such media allow the identification of yeasts from color contrast of the colonies, produced due to reactions of species-specific enzymes with the chromogenic substrate ${ }^{30}$. Their advantage is to allow the identification of different isolates in a single plaque and to provide an effective presumptive identification of $C$. albicans, C. tropicalis and C. krusei based on morphology and color of the reaction (light green, dark blue and pink, respectively $)^{31,32}$.

Table 2: Yeast species submitted to different identification methods.

\begin{tabular}{|c|c|c|c|c|}
\hline $\begin{array}{c}\text { Number of } \\
\text { isolates }\end{array}$ & $\begin{array}{c}\text { VITEK }^{\circledR} \text { MS } \\
\text { (MALDI-TOF) }\end{array}$ & $\begin{array}{l}\text { VITEK }^{\circledR} 2 \\
\text { Compact } \\
\end{array}$ & $\begin{array}{l}\text { Microculture on } \\
\text { corn meal agar }\end{array}$ & CHROMagar $^{8}$ \\
\hline ATCC 6258 & C. krusei & C. krusei & C. krusei & $\begin{array}{l}\text { Inconclusive } \\
\text { identification }\end{array}$ \\
\hline ATCC 22019 & C. parapsilosis & C. parapsilosis & C. parapsilosis & * \\
\hline ATCC 14243 & C. krusei & C. krusei & C. krusei & C. krusei \\
\hline ATCC 10231 & C. albicans & C. albicans & C. albicans & C. albicans \\
\hline 17 & C. parapsilosis & C. parapsilosis & C. parapsilosis & * \\
\hline 15 & C. albicans & C. albicans & C. albicans & C. albicans \\
\hline 10 & C. tropicalis & C. tropicalis & C. tropicalis & C. tropicalis \\
\hline 6 & C. albicans & C. albicans & $\begin{array}{l}\text { Inconclusive } \\
\text { identification }\end{array}$ & C. albicans \\
\hline 6 & C. glabrata & C. glabrata & C. glabrata & * \\
\hline 3 & C. parapsilosis & C. parapsilosis & $\begin{array}{l}\text { Inconclusive } \\
\text { identification }\end{array}$ & * \\
\hline 2 & C. neoformans & C. neoformans & C. neoformans & * \\
\hline 1 & C. albicans & C. spherica & C. albicans & $\begin{array}{l}\text { Inconclusive } \\
\text { identification }\end{array}$ \\
\hline 1 & C. albicans & $\begin{array}{l}\text { Inconclusive } \\
\text { identification }\end{array}$ & $\begin{array}{l}\text { Inconclusive } \\
\text { identification }\end{array}$ & C. albicans \\
\hline 1 & C. famata & C. famata & C. albicans & * \\
\hline 1 & C. intermedia & C. intermedia & $\begin{array}{l}\text { Inconclusive } \\
\text { identification }\end{array}$ & * \\
\hline 1 & C. krusei & C. krusei & C. parapsilosis & C. krusei \\
\hline 1 & C. krusei & $\begin{array}{l}\text { Inconclusive } \\
\text { identification }\end{array}$ & $\begin{array}{l}\text { Inconclusive } \\
\text { identification }\end{array}$ & $\begin{array}{l}\text { Inconclusive } \\
\text { identification }\end{array}$ \\
\hline 1 & C. parapsilosis & C. parapsilosis & $\begin{array}{l}\text { Inconclusive } \\
\text { identification }\end{array}$ & * \\
\hline 1 & C. parapsilosis & C. tropicalis & C. parapsilosis & * \\
\hline 1 & C. parapsilosis & C. parapsilosis & C. tropicalis & * \\
\hline 1 & C. parapsilosis & C. parapsilosis & C. glabrata & * \\
\hline 1 & C. tropicalis & C. tropicalis & $\begin{array}{l}\text { Inconclusive } \\
\text { identification }\end{array}$ & $\begin{array}{l}\text { Inconclusive } \\
\text { identification }\end{array}$ \\
\hline 1 & C. tropicalis & C. tropicalis & C. parapsilosis & C. tropicalis \\
\hline 1 & $\begin{array}{l}\text { Inconclusive } \\
\text { identification }\end{array}$ & $\begin{array}{l}\text { Inconclusive } \\
\text { identification }\end{array}$ & $\begin{array}{l}\text { Inconclusive } \\
\text { identification }\end{array}$ & * \\
\hline 1 & S. cerevisiae & S. cerevisiae & $\begin{array}{l}\text { Inconclusive } \\
\text { identification }\end{array}$ & * \\
\hline 1 & T. asahii & T. asahii & $\begin{array}{l}\text { Inconclusive } \\
\text { identification }\end{array}$ & * \\
\hline 1 & T. asteroides & $\begin{array}{l}\text { Inconclusive } \\
\text { identification }\end{array}$ & C. glabrata & * \\
\hline
\end{tabular}

*Method applied only to $C$. albicans, C. tropicalis and C. krusei species identified by VITEK ${ }^{\circledast}$ MS. 
The chromogenic medium used in our study was able to identify $95.8 \%(n=23)$ of $C$. albicans samples and $91.7 \%(n=11)$ of $C$. tropicalis samples (Figure 1$)$. This result demonstrates good efficiency together with reduced cost for the presumptive identification of several samples, which is in agreement with the findings of previous studies, in which $90 \%$ of the samples were identified ${ }^{33}$. With regard to C. krusei, the chromogenic medium was able to identify $50 \%$ of the strains. However, only four isolates of this species were included in the study. As other Candida spp. also produce a pink reaction, similar to C. krusei, doubts regarding the identification of this species by CHROMagar may eventually occur. Although it is useful in the identification of some species, accelerating the laboratory routine, the chromogenic medium alone is not able to identify all species that may be present, requiring additional identification methods, especially when considering a large laboratory routine.

Regarding the use of microculture on corn meal-Tween 80 agar, an identification rate of $70.9 \%$ was observed (Figure 2), contrasting with other studies that found a rate of up to $92 \%{ }^{33}$. Among all samples, 17 had inconclusive identification and 6 did not agree with the other methods. This technique depends fundamentally on the procedures performed and the expertise of the analyst. For a large number of samples and for urgent cases, limitations can be observed because processing is manual and requires more time. Another fact of great relevance and similar to what occurs with chromogenic media is the inability to identify less common species. Thus, a lack of ability in the differentiation of $C$. haemulonii, C. lipolytica, C. Iusitaniae, C. famata and C. pelliculosa ${ }^{33}$ has been reported.

For the VITEK ${ }^{\otimes} 2$ Compact system the identification rate was $92.4 \%$, higher than those observed in the previous methods (Figure 3 ). Four strains were not identified and two did not agree with the other methods. Other studies have shown similar results, and several studies have found that more than $93 \%$ of the strains analyzed were correctly identified ${ }^{26,34-37}$ and could reach up to $98.3 \%$ concordance ${ }^{38}$. In addition, rates of $86.36 \%{ }^{39}, 92.1 \%{ }^{40}, 93 \%{ }^{41}$ and $91 \%^{42}$ have been determined, also in agreement with the present study. Finally, a similar study, by means of a joint evaluation of micromorphology obtained in corn meal agar and cultivation in chromogenic agar versus use of the VITEK ${ }^{\circledR} 2$ Compact system, also observed a high percentage of accuracy $(97 \%)^{33}$.

The results for VITEK ${ }^{\circledR} 2$ Compact system are known to be good, as well as the speed of analysis ${ }^{43}$; however, wrong results may occur. Thus, the use of molecular analysis is required, leading to a higher cost and the need for specialized labor, and this is not the case in most microbiology laboratories ${ }^{39}$.

Therefore, MALDI-TOF mass spectrometry using VITEK ${ }^{\circledR}$ MS has been shown to be a revolutionary method

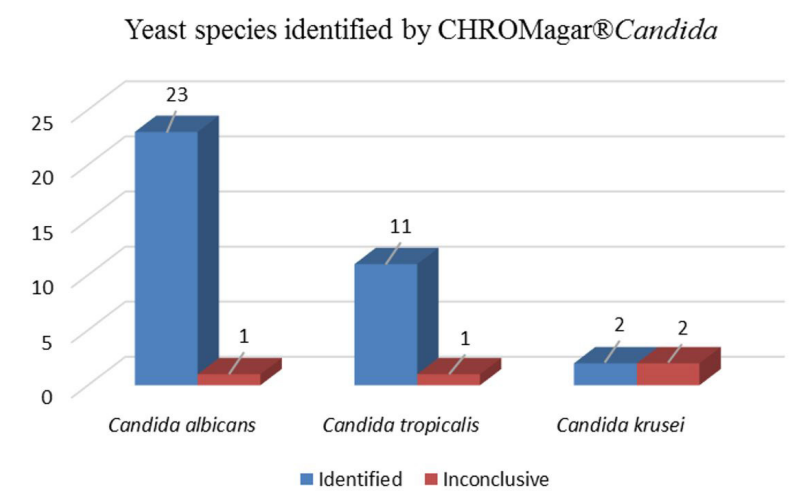

Figure 1: Yeast species identified by CHROMagar ${ }^{\circledR}$ Candida.

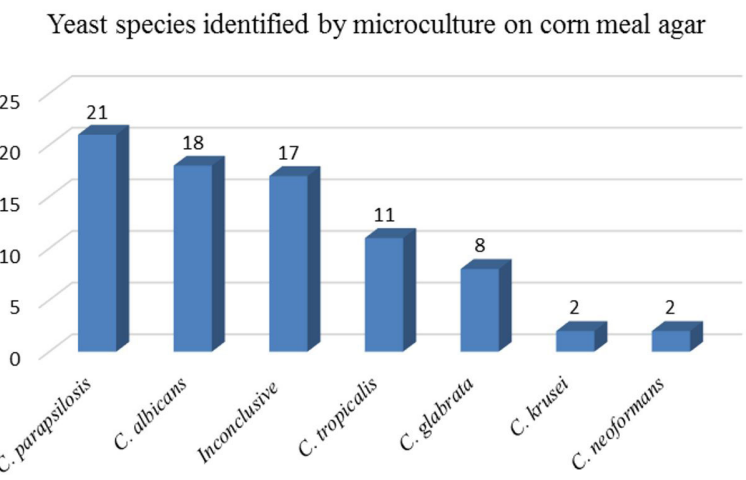

Figure 2: Yeast species identified by microculture on corn meal agar.

Yeast species identified by the VITEK 2 Compact

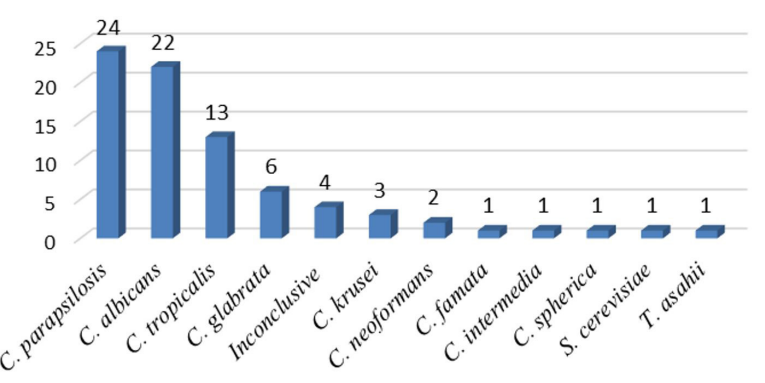

Figure 3: Yeast species identified by the VITEK ${ }^{\circledR} 2$ Compact.

in clinical microbiology laboratories. Considering all the techniques analyzed, it had the best performance, identifying $98.7 \%$ of the samples $(n=78)$ (Figure 4$)$. Similarly, high rates of successful identification were found elsewhere $\left(97.8 \%^{44}\right.$ and $\left.97.5 \%{ }^{45}\right)$.

In summary, considering the efficiency in the identification of the species and regardless of disagreements between the methods evaluated, there was a variation that reached 78 identified strains from the 79 used ones. Figure 5 shows the percentage of samples not identified by each method used. The automated methods had the best performances; 
Yeast species identified by VITEK ${ }^{\circledR}$ MS (MALDITOF)

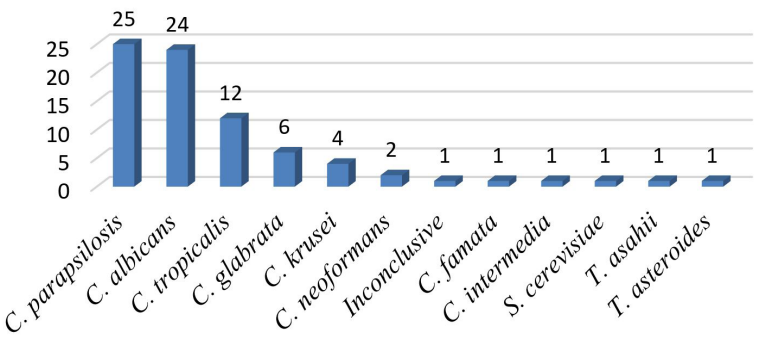

Figure 4: Yeast species identified by VITEK ${ }^{\circledR}$ MS (MALDI-TOF).

Isolates not identified by the methodologies evaluated

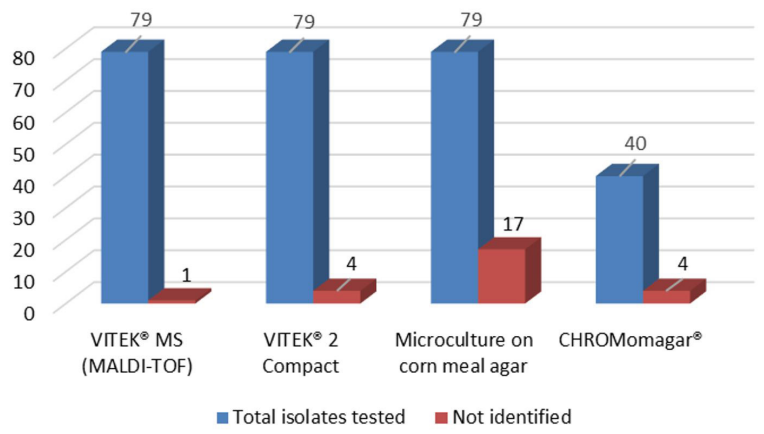

Figure 5: Isolates not identified by the methods evaluated. however, to determine the technique to be used, each situation should be evaluated separately, as costs and speed of results should be considered according to laboratory routine and need of each institution.

\section{CONCLUSION}

Because yeast infections may represent a considerable threat for patients and several pathogenic species are not usually identified by conventional and manual methods, together with a variable susceptibility to antifungal agents, a correct and fast identification of the species involved in infectious processes is of fundamental importance for therapeutic success and patient survival. Automated techniques such as VITEK ${ }^{\circledR} 2$ Compact and VITEK ${ }^{\circledR}$ MS systems had the best performances, and MALDI-TOF mass spectrometry also has the advantage of being faster and cheaper. However, it is worth mentioning that chromogenic media can be useful as well. Although it was not able to identify most samples, it showed good efficiency in the determination of $C$. albicans and C. tropicalis, which are very common in laboratory routine. Therefore, chromogenic media can serve as a screening tool to decide whether samples should be submitted to more complex methods.

\section{Conflicts of interest}

The authors declare no conflicts of interest.

\section{REFERENCES}

1. Diamond RD. The growing problem of mycoses in patients infected with the human immunodeficiency virus. Rev Infect Dis. 1991;13(3):480-6. http:// dx.doi.org/10.1093/clinids/13.3.480. PMid:1866553.

2. Fridkin SK, Jarvis WR. Epidemiology of nosocomial fungal infections. Clin Microbiol Rev. 1996;9(4):499-511. http://dx.doi.org/10.1128/CMR.9.4.499. PMid:8894349.

3. Morrison VA, Haake RJ, Weisdorf DJ. Non-Candida fungal infections after bone marrow transplantation: risk factors and outcome. Am J Med. 1994;96(6):497-503. http://dx.doi. org/10.1016/0002-9343(94)90088-4. PMid:8017446.

4. Pfaller MA, Wenzel RP. The epidemiology of fungal infections. In Anaisse EJ, McGinnis MR, Pfaller MA, editors. Clinical mycology. Phyladelphia: Elsevier; 2003. p. 3-19.

5. Warnock DW. Trends in the epidemiology of invasive fungal infections. Nihon Ishinkin Gakkai Zasshi. 2007;48(1):1-12. PMid:17287717.
6. Rex JH, Walsh TJ, Sobel JD, Filler SG, Pappas PG, Dismukes WE, et al. Practice guidelines for the treatment of candidiasis. Clin Infect Dis. 2000;30(4):662-78. PMid:10770728.

7. Baumgartner C, Freydiere AM, Gille $Y$. Direct identification and recognition of yeast species from clinical material by using albicans ID and CHROMagar Candida plates. $J$ Clin Microbiol. 1996;34(2):454-6.

8. Foongladda S, Haouharn P, Sakulmaiwatana $P$, Chaiprasert A. Comparative evalution of Candi Select test and conventional methods for identification of Candida albicans in routine clinical isolates. Mycoses. 2002;45(34):75-8. http://dx.doi.org/10.1046/ j.1439-0507.2002.00728.x. PMid:12000504.

9. Pfaller MA, Diekema DJ. Epidemiology of invasive candidiasis: a persistent public health problem. Clin Microbiol Rev. 2007;20(1):133-63. http:// dx.doi.org/10.1128/CMR.00029-06. PMid:17223626.
10. Pfaller MA, Houston A, Coffmann S. Application of CHROMagar Candida for rapid screening of clinical specimens for Candida albicans, Candida tropicalis, Candida krusei, and Candida (Torulopsis) glabrata. J Clin Microbiol. 1996;34(1):58-61. PMid:8748273.

11. Freydiere AM, Guinet R, Boiron $P$. Yeast identification in the clinical microbiology laboratory: phenotypical methods. Med Mycol. 2001;39(1):9-33. http://dx.doi. org/10.1080/mmy.39.1.9.33. PMid:11270413.

12. Koehler AP, Chu KC, Houang ETS, Cheng AFB. Simple, reliable, and cost-effective yeast identification scheme for the clinical laboratory. J Clin Microbiol. 1999;37(2):422-6. PMid:9889232.

13. Letscher-Bru V, Meyer MH, Galoisy AC, Waller J, Candolfi E. Prospective evaluation of the new chromogenic medium Candida ID, in comparison with Candiselect, for isolation of molds and isolation and presumptive identification of yeast species. J Clin 
Microbiol. 2002;40(4):1508-10. http:// dx.doi.org/10.1128/JCM.40.4.15081510.2002. PMid:11923383.

14. Bauters TG, Nelis HJ. Comparison of chromogenic and fluorogenic membrane filtration methods for detection of four Candida species. J Clin Microbiol. 2002;40(5):18389. http://dx.doi.org/10.1128/ JCM.40.5.1838-1839.2002. PMid:11980972.

15. Colombo AL, Guimarães TT. Epidemiology of hematogenous infections due to Candida spp. Rev Soc Bras Med Trop. 2003;36(5):599607. http://dx.doi.org/10.1590/ S0037-86822003000500010. PMid:14576875.

16. Godoy P, Tiraboschi IN, Severo LC, Bustamante B, Calvo B, Almeida LP, et al. Species distribution and antifungal susceptibility profile of Candida spp. Bloodstream isolates from Latin American hospitals. Mem Inst Oswaldo Cruz. 2003;98(3):4015. http://dx.doi.org/10.1590/ S0074-02762003000300020. PMid:12886424.

17. Matta DA, Almeida LP, Machado AM, Azevedo AC, Kusano EJ, Travassos $\mathrm{NF}$, et al. Antifungal susceptibility of 1,000 Candida bloodstream isolates to 5 antifungal drugs: results of a multicenter study conducted in São Paulo, Brazil, 1995. Diagn Microbiol Infect Dis. 2007;57(4):399404. http://dx.doi.org/10.1016/j. diagmicrobio.2006.10.011. PMid:17240110.

18. Croxatto A, Prod'hom G, Greub G. Applications of MALDI-TOF mass spectrometry in clinical diagnostic microbiology. FEMS Microbiol Rev. 2012;36(2):380-407. http://dx.doi.org/10.1111/j.15746976.2011.00298.x. PMid:22092265.

19. Carrillo-Muñoz AJ, Quindós G, Cárdenes $\mathrm{CD}$, Alonso-Vargas $\mathrm{R}$, Arévalo $P$, Brió $S$, et al. Evalución del spéc Chromalbicans Agar para la identificación presuntiva de Candida albicans. Rev Iberoam Micol. 2001;18(3):105-8. PMid:15487917.

20. Cooke VM, Miles RJ, Price RG, Midgley G, Khamri W, Richardson AC. New chromogenic agar medium for the identification of Candida spp. Appl Environ Microbiol. 2002;68(7):36227. http://dx.doi.org/10.1128/ AEM.68.7.3622-3627.2002. PMid:12089051.
21. García-Martos $P$, García-Agudo R, Hernándes-Molina JM, Marín P, Tarello E, Mira J. Identificación de levaduras de interés clínico ver el spéc de cultivo CHROMagar Candida. Rev Iberoam Micol. 1998;15:131-5.

22. Pfaller MA, Houston A, Coffmann S. Application of CHROMagar Candida for rapid screening of clinical specimens for Candida albicans, Candida tropicalis, Candida krusei, and Candida (Torulopsis) glabrata. J Clin Microbiol. 1996;34(1):58-61. PMid:8748273.

23. Lacaz CS, Porto E, Martins JEC. Micologia médica: fungos, actinomicetos e algas de interesse médico. São Paulo: Savier; 2002.

24. Zimbro MJ, Power DA, Miller SM, Wilson GE, Johnson JA, editors. Difco \& BBL manual: manual of microbiological culture media. 1st ed. Maryland: Becton, Dickinson and Company; 2003.

25. Sidrim JJC, Rocha MFG. Micologia médica à luz de autores contemporâneos. Rio de Janeiro: Guanabara Koogan; 2004.

26. Aubertine CL, Rivera M, Rohan SM, Larone $\mathrm{DH}$. Comparative study of the new colorimetric VITEK 2 yeast identification card versus the older fluorometric card and of $\mathrm{CHROMagar}$ Candida as a source medium with the new card. J Clin Microbiol. 2006;44(1):227-8. http://dx.doi. org/10.1128/JCM.44.1.227-228.2006. PMid:16390976.

27. Carbonnelle E, Nassif X. Applications of MALDI-TOF-MS in clinical microbiology laboratory. Médecine Sci MS. 2011;27(10):882-8. PMid:22027426.

28. Colombo AL, Nucci M, Park BJ, Nouér SA, Arthington-Skaggs $B$, Matta DA, et al. Epidemiology of candidemia in Brazil: a nationwide sentinel surveillance of candidemia in eleven medical centers. $J$ Clin Microbiol. 2006;44(8):2816-23. http:// dx.doi.org/10.1128/JCM.00773-06. PMid:16891497.

29. Pfaller MA, Messer SA, Boyken L, Huynh H, Hollis RJ, Diekema DJ. In vitro activities of 5 -fl uorocytosine against 8,803 clinical isolates of Candida spp.: global assessment of primary resistance using National Committee for Clinical Laboratory Standards susceptibility testing methods. Antimicrob Agents
Chemother. 2002;46(11):351821. http://dx.doi.org/10.1128/ AAC.46.11.3518-3521.2002. PMid:12384359.

30. Williams DW, Lewis MAO. Isolation and identification of Candida from the oral cavity. Oral Dis. 2000;6(1):3-11. http://dx.doi. org/10.1111/j.1601-0825.2000. tb00314.x. PMid:10673781.

31. Beighton D, Ludford R, Clark DT, Brailsford SR, Pankhurst CL, Tinsley GF, et al. Use of CHROMagar Candida medium for isolation of yeast from dental samples. J Clin Microbiol. 1995;33(11):3025-7. PMid:8576366.

32. Willinger B, Manafi M. Evaluation of CHROMagar Candida for rapid screening of clinical specimens for Candida species. Mycoses. 1999;42(1-2):61-5. http://dx.doi.org/10.1046/j.14390507.1999.00406.x. PMid:10394850.

33. Kumar S, Vyas A, Kumar M, Mehra SK. Application of CHROMagar Candida for identification of clinically important Candida species and their antifungal susceptibility pattern. Int $J$ Biol Med Res. 2013 [cited 2019 Apr 15];4:3600-6. Available from: http:// www.biomedscidirect.com/1390/ application_of_chromagar_candida_ for_identification_of_clinically_ important_candida_species_and_ their_antifungal_susceptibility_pattern/ articlescategories

34. Hata DJ, Hall L, Fothergill A, Larone $\mathrm{D}$, Wengenack N. Multicenter evaluation of the new Vitek 2 advanced colorimetric yeast identification card. J Clin Microbiol. 2007;45(4):1087-92. http://dx.doi. org/10.1128/JCM.01754-06. PMid:17267631.

35. Massonet C, Van Eldere J, Vaneechoutte M, De Baere T, Verhaegen J, Lagrou K. Comparison of Vitek 2 with ITS2- fragment length polymorphism analysis for identification of yeast species. $J$ Clin Microbiol. 2004;42(5):2209-11. http:// dx.doi.org/10.1128/JCM.42.5.22092211.2004. PMid:15131191.

36. Sanguinetti M, Porta R, Sali M, La Sorda M, Pecorini G, Fadda G, et al. Evaluation of Vitek 2 and RapID Yeast Plus System for yeast species identification: experience at a large clinical microbiology laboratory. J Clin Microbiol. 2007;45(4):1343-6. http:// dx.doi.org/10.1128/JCM.02469-06. PMid:17287333. 
37. Valenza G, Strasen J, Schäfer F, Frosch M, Kurzai O, Abele-Horn M. Evaluation of new colorimetric Vitek 2 yeast identification card by use of different source media. J Clin Microbiol. 2008;46(11):3784-7. http:// dx.doi.org/10.1128/JCM.01318-08 PMid:18799700.

38. Ochiuzzi ME, Cataldi S, Guelfand L, Maldonado I, Arechavala A. Evaluación del sistema Vitek 2 para la identificación de las principales spécies de levaduras del género Candida. Rer Argent Microbiol. 2014;46(2):107-10. http://dx.doi. org/10.1016/S0325-7541(14)70057-4

39. Higashi CM, Takashima $\mathrm{FH}$, Rechenchoski DZ, Stipp-Abe AT, Vespero EC, Quesada RMB, et al. Comparação do sistema de identificação automatizado Vitek 2 e PCR-ITS para caracterização das espécies dos isolados clínicos de Candida spp. Semin Cienc Biol Saude. 2015;36(1):233-42. http://dx.doi.org/10.5433/16790367.2015v36n1Suplp233.
40. Graf B, Adam T, Zill E, Gobel UB. Evaluation of the vitek 2 system for rapid Identification of yeasts and yeast-like organisms. J Clin Microbiol. 2000;38(5):1782-5. PMid:10790099.

41. Freydiere AM, Guinet R, Boiron $P$. Yeast identification in the clinical microbiology laboratory: phenotypical methods. Med Mycol. 2001;39(1):9-33. http://dx.doi. org/10.1080/mmy.39.1.9.33. PMid:11270413.

42. Meletiadis J, Arabatzis M, Bompola M, Tsiveriotis K, Hini S, Petinaki $\mathrm{E}$, et al. Comparative evaluation of three commercial identification systems using common and rare bloodstream yeast isolates. $J$ Clin Microbiol. 2011;49(7):2722-7. http:// dx.doi.org/10.1128/JCM.01253-10. PMid:21543578.

43. Melhem MSC, Bertoletti A, Lucca HRL, Silva RBO, Meneghin FA, Szeszs MW. Use of the VITEK 2 system to identify and test the antifungal susceptibility of clinically relevant yeast species. Braz J Microbiol. 2014;44(4):125766. http://dx.doi.org/10.1590/ S1517-83822014005000018. PMid:24688520.

44. Ghosh AK, Paul S, Sood P, Rudramurthy SM, Rajbanshi A, Jillwin TJ, et al. Matrix-assisted laser desorption ionization timeof-flight mass spectrometry for the rapid identification of yeasts causing bloodstream infections. Clin Microbiol Infect. 2015;21(4):3728. http://dx.doi.org/10.1016/j. cmi.2014.11.009. PMid:25658527.

45. Wang $W$, Xi H, Huang M, Wang J, Fan M, Chen Y, et al. Performance of mass spectrometric identification of bacteria and yeasts routinely isolated in a clinical microbiology laboratory using MALDITOF MS. $J$ Thorac Dis. 2014;6(5):524-33. PMid:24822114. 